\title{
Tax Incentive Provisions And The User Cost Of Capital: The Case Of Greece
}

Thomas A. Anastassiou, (Email: anastassiou@aueb.gr), Athens University of Economics and Business

\begin{abstract}
According to the neoclassical framework the quantitative influence of tax policy measures on capital spending is exercised through the parameters that define the desired stock of capital and more specifically through the user cost determinant (c). A tax-adjusted user cost expression is formulated and time series of user cost are calculated using the usual tax parameters (like depreciation allowances, tax credits, investment grants, investment allowances and the like) that are incorporated in the value of $c$ and which have been taken from the Greek tax incentive structure. The test of fiscal parameters on investment was made for the two kinds of capital assets, equipment and structures, since expenditure on these two comprise on average an almost 85 per cent of total manufacturing investment in Greece. What the research showed for the period under investigation was that $c$, the cost of capital variable, was not affected much by tax provisions, and in its turn could not affect decisively the desired level of capital stock and thus the amount of net investment.(JEL: E62)
\end{abstract}

\section{INTRODUCTION}

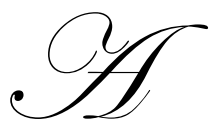

major contribution of the neoclassical theory as developed by Jorgenson and his associates is offered in the field of analyzing the quantitative influence of tax policy measures on investment spending. The idea is based upon the sensitivity of investment to changes in the desired capital stock. It is assumed that businessmen take full and complete account of the incentives when deciding upon their desired capital stock. The effect of tax is exercised through the parameters that define the desired stock of capital and more specifically through the user cost determinant.

The theoretical framework necessary to indicate the way the rental price of capital is formulated and how are fiscal parameters entered in its calculation is presented in Part 2; usual tax parameters that are incorporated in the value of $\mathrm{c}$ and that are presently considered, refer to tax credits, investment grants, investment allowances, initial allowances, and the like. Before deriving time series for user cost and commenting on their pattern (Part 4), an inquiry as to the operative nature of incentive provisions for Greece is made and relevant to user cost determinants are calculated (Part 3), given that all these would finally formulate the user cost variable. Conclusions are drawn in Part 5.

\section{A TAX-ADJUSTED RENTAL PRICE OF CAPITAL}

Let us suppose the firm is considering increasing its capital stock by one unit. This will require a current outlay of, say, q euros, while replacement expenditures in each future period will have to be increased by q $\delta$, with $\delta$ being the rate of replacement. Given the price

of output $\mathrm{p}$ and the marginal product of capital $(\partial \mathrm{Q} / \partial \mathrm{K})$, gross revenues in each future period will be increased by $\mathrm{p}(\partial \mathrm{Q} / \partial \mathrm{K})$. However, the net revenue in each future period will be increased by only $p\left(\frac{\partial Q}{\partial K}\right)-q \delta-T_{i}$, where $T_{i}$ is the increase in direct taxes that must be paid in period $i$. Defining $D_{i}$ as the increase in depreciation 
charges for tax purposes in period $i$, we have $T_{i}=t\left(p \frac{\partial Q}{\partial K}-D_{i}\right)$ where $\mathrm{t}$ is the tax rate on firm's income. The investment would be worth undertaking if the discounted value of the increases in net revenue exceeds the price of capital, i.e.

$\sum_{i=1}^{\infty}\left\{(1-t) p \frac{\partial Q}{\partial K}-q \delta+t D_{i}\right\}(1+r)^{-i} \geq q$

or

$\sum_{i=1}^{\infty}\left\{(1-t) p \frac{\partial Q}{\partial K}-q \delta\right\}(1+r)^{-i}+t \cdot \sum_{i=1}^{\infty} D_{i}(1+r)^{-i} \geq q$

with $r$ being the rate of discount. Tax depreciation charges will be increased as a result of the initial outlay of q euros, and will also be increased as a result of the replacement expenditures of q $\delta$ made in each future period. If $d_{i}$ is the amount of tax depreciation permitted per euro investment $i$ periods after the investment is made, then the discounted value of depreciation charges stemming from the initial outlay q will be $\sum_{i=1}^{\infty} q d_{i}(1+r)^{-i}$. The discounted value of depreciation charges stemming from $\mathrm{q} \delta$ of replacement in the next period will be $\sum_{i=1}^{\infty} q \delta d_{i}(1+r)^{-i-1}$, one period after will $\sum_{i=1}^{\infty} q \delta d_{i}(1+r)^{-i-2}$ and so on. Defining by z the present value of depreciation charges stemming from a euro investment, i.e. ${ }^{1}$

$z=d_{i}(1+r)^{-1}+d_{2}(1+r)^{-2}+d_{3}(1+r)^{-3}+\ldots \ldots . .=\sum_{i=1}^{\infty} d_{i}(1+r)^{-i}$

then

$\sum_{i=1}^{\infty} D_{i}(1+r)^{-i}=q z+q \delta z \sum_{i=1}^{\infty}(1+r)^{-i}$

Hence, the firm should add one unit to its capital stock if

$\sum_{i=1}^{\infty}\left\{(1-t) p \frac{\partial Q}{\partial K}-q \delta+t q \delta z\right\}(1+r)^{-i} \geq q(1-t z)$

that is the discounted value of the increase in net revenue exceeds the net cost of a unit of capital. The latter expression can be written

$\left\{(1-t) p \frac{\partial Q}{\partial K}-q \delta(1-t z)\right\} \frac{1}{r} \geq q(1-t z)$ or

$p \frac{\partial Q}{\partial K} \geq \frac{q(r+\delta)(1-t z)}{(1-t)}=c$

where $\mathrm{c}$ is the tax-adjusted rental price of capital. The firm should continue to expand its capital stock until the marginal product of capital $\frac{\partial Q}{\partial K}$ is equal to the real price of capital $\mathrm{c} / \mathrm{p}$. The simplified derivation above was first presented by Coen (1968).

Originally Jorgenson and his collaborators introduced a more complicated tax-adjusted user cost expression where some unobservable and unstable parameters were intervened and which expression had firms looking 
backwards with concern on past price variations. An alternative expression of the above form was presented later by Hall and Jorgenson (1967). The assumption underlying expression (4) is that the firm is looking forwards rather than backwards with static expectations. Past price variations are ignored and fiscal parameters are expected to remain constant.

According to (4) if there are no direct taxes on the firm's income, the fiscal term (1-tz)/(1-t) disappears, and the user cost of capital is simply expressed by

$$
c=q(r+\delta)
$$

Taking $q=\mathrm{d}_{\mathrm{q}} / \mathrm{d}_{\mathrm{t}}$ as the rate of change in the price (q) of investment goods, expressions (5) and (4) are transformed to

$$
c=q(r+\delta)-\dot{q}
$$

and

$$
\mathrm{c}=\mathrm{q}(\mathrm{r}+\delta-\dot{q}) \frac{(1-t z)}{(1-t)}
$$

A direct tax with no depreciation allowances $(\mathrm{z}=0)$ increases user cost by the factor $1 /(1-\mathrm{t})$; a depreciation allowance reduces user cost by the factor $(1-\mathrm{tz})$, $\mathrm{tz}$ being the discounted value of tax savings which are expected to follow from one unit value of fixed investment. In the case of immediate expensing (i.e. deduction of the cost of capital goods in the year of purchase), $\mathrm{z}$ will be unity and the existence of the direct tax would not alter user cost. ${ }^{2}$ The tax system in the latter case is said to be 'neutral' meaning that investment decisions are not influenced by taxation.

To make exposition easier the incorporation of other fiscal parameters in the calculation of c, as for example tax credits, investment grants, investment allowances, initial allowances, etc., has not been considered. It is an easy matter to incorporate any of these tax instruments in the above user cost expression. For the U.S. tax structure (Hall and Jorgenson, 1971, Coen, 1971) the existence of a tax credit (k) will provide the following user cost expression

$$
c=q(r+\delta) \frac{(1-k)(1-t z)}{(1-t)}
$$

or

$$
c=q(r+\delta) \frac{(1-k-t z)}{(1-t)}
$$

depending on whether the tax credit is deducted (8) or not (9) from the depreciable base of acquisitions. The inclusion of an investment grant can be made in a similar way. The effect of investment allowances or initial allowances needs to be incorporated in the calculation of the value of $\mathrm{z}$ since they represent relief which is given as a deduction from taxable income and not as a credit against tax. For an investment allowance of $\lambda$ per cent per euro investment, the value of $\mathrm{z}$ will be

$$
z=\sum_{i=1}^{n} d_{i}(1+r)^{-i}+\lambda
$$

if, for example, the investment allowance is claimed in addition to depreciation allowances. ${ }^{3}$ Accelerated depreciation, if it is given as an increase in the permitted per year tax depreciation allowance percentage, will obviously be reflected in the $d_{i}$ rate. 


\section{THE VALUE OF Z IN THE GREEK MANUFACTURING INDUSTRY}

Using the neoclassical framework, the value of $\mathrm{z}$ as we saw, will be given by: $z=\sum_{i=1}^{n} d_{i}(1+r)^{-i}$

Given the value of $z$, if the revenues of a firm are taxed at rate $t$, then $t z$ will represent the discounted value of tax savings which are expected to follow from a unit value of fixed investment. Furthermore, variations in the value of $\mathrm{z}$, when $\mathrm{t}$ is constant (or nearly constant, as it is found to be the case in Greece during the sample period), will make the implicit rental price of capital (c) vary, thus making an investment project cheaper or more expensive in relation to various time periods.

In Table (1), using the depreciation rates for tax purposes ${ }^{4}$, and for Area A (Athens-Piraeus and surrounding areas comprising the Department of Attica), the corresponding values of $\mathrm{z}$ have been calculated for equipment and buildings. It was chosen to report on Area A, since it is believed (and there are a lot of indications to support this supposition $)^{5}$ that the representative firm is situated in the Attica Department. The discount rate used was taken to be an annual average of the long term loans interest rate for manufacturing, supplied by the Bank of Greece, as depreciation deductions are expressed in nominal terms.

The values of $\mathrm{z}$ for equipment are generally higher than those for buildings given the sorter useful life for tax purposes recognized for these assets. In addition one can observe from a diagrammatic representation of the trend of $\mathrm{z}$ since 1950, that most of the time $\mathrm{z}$ has remained virtually constant with no serious fluctuations that could cause important changes in the value of the user cost of capital.

Other tax allowances that can now be considered are tax-free reserves, investment deductions and investment allowances that have been provided by the Greek tax system. ${ }^{6}$ The provisions for tax-free reserves and investment deductions cannot be incorporated mechanistically into the calculation of $\mathrm{z}$. These two provisions are completely dependent on the amount of net profits. A 100 per cent deduction of net profits completely deprived tax authorities of any tax revenues from new investments. Similarly, a 50 per cent deduction of net profits before 1967 for the representative firm, could have had the same results on government revenue if one considers also the various depreciation allowances in use at that time. ${ }^{7}$ Mainly after 1972, when all these net profit deduction provisions were abolished, and the new system of investment allowances started to be applied, corporate tax- revenues began to increase substantially given also that no investment allowances were available for the representative firm of Area A.

The application of investment allowances in the value of $\mathrm{z}$ will provide a new time series for $\mathrm{z}$ under the assumption however that firms' profits were enough to absorb the allowances available to them. In a relevant search (Anastassiou, 2005) it has been found though that investment allowances were not operative for marginal investments and this has been tested by comparing manufacturing investment outlays and the maximum amount of net profits that could be deducted each year for investment expenditures. The later figures (derived from the application of tax allowances to the amount of net profits as defined by Greek law) were found to be on average much lower than gross investment realized each year, suggesting the ineffectiveness of incentive provisions at the margin. This provides new grounds in the use of various formulas that are applied below for the calculation of c.

\section{USER COST OF CAPITAL CALCULATIONS}

The effect of tax provisions on investment behavior within the neoclassical framework is assessed through the calculation of the user cost of capital. Recalling a previous Part, the user cost expression with no tax considerations was given by

$c=q(r+\delta)-\dot{q}$ 
If taxation is introduced, the value of $\mathrm{c}$ becomes

$$
c=q(r+\delta) \frac{(1-t z)}{(1-t)}
$$

and when $q$ is taken into consideration the latter expression is written

$$
c=q(r+\delta-\dot{q}) \frac{(1-t z)}{(1-t)}
$$

Table 1

\begin{tabular}{|c|c|c|c|c|c|c|c|}
\hline \multirow[b]{2}{*}{ Year } & \multicolumn{3}{|c|}{ Equipment } & \multicolumn{3}{|c|}{ Buildings } & \multirow[b]{2}{*}{$\begin{array}{l}\text { Discount } \\
\text { Rate }(\%)\end{array}$} \\
\hline & $\begin{array}{l}\text { Depreciation } \\
\text { Rate }\left(d_{i}\right)\end{array}$ & $\begin{array}{l}\text { Tax Life } \\
\left(n_{i}=\frac{1}{d_{i}}\right)\end{array}$ & $\sum_{i=1}^{n} \frac{d_{i}}{(1+r)^{i}}=z$ & $\begin{array}{l}\text { Depreciation } \\
\text { Rate }\left(d_{i}\right)\end{array}$ & $\begin{array}{l}\text { Tax Life } \\
\left(n_{i}=\frac{1}{d_{i}}\right)\end{array}$ & $\sum_{i=1}^{n} \frac{d_{i}}{(1+r)^{i}}=z$ & \\
\hline 1950 & 0.2000 & 5.00 & 0.7209 & 0.1000 & 10.00 & 0.5650 & 12.00 \\
\hline 1951 & 0.2000 & 5.00 & 0.7209 & 0.1000 & 10.00 & 0.5650 & 12.00 \\
\hline 1952 & 0.2000 & 5.00 & 0.7209 & 0.1000 & 10.00 & 0.5650 & 12.00 \\
\hline 1953 & 0.2000 & 5.00 & 0.7209 & 0.1000 & 10.00 & 0.5650 & 12.00 \\
\hline $1954^{1}$ & 0.2000 & 5.00 & 0.7582 & 0.1000 & 10.00 & 0.6145 & 10.00 \\
\hline $1954^{2}$ & 0.1400 & 7.14 & 0.7525 & 0.0750 & 13.33 & 0.5538 & 10.00 \\
\hline 1955 & 0.1400 & 7.14 & 0.7803 & 0.0750 & 13.33 & 0.5853 & 9.00 \\
\hline 1956 & 0.1400 & 7.14 & 0.7525 & 0.0750 & 13.33 & 0.5538 & 10.00 \\
\hline 1957 & 0.1400 & 7.14 & 0.7525 & 0.0750 & 13.33 & 0.5538 & 10.00 \\
\hline 1958 & 0.2100 & 4.76 & 0.7991 & 0.1125 & 8.89 & 0.6484 & 10.00 \\
\hline 1959 & 0.2100 & 4.76 & 0.8429 & 0.1125 & 8.89 & 0.7056 & 7.92 \\
\hline 1960 & 0.2100 & 4.76 & 0.8635 & 0.1125 & 8.89 & 0.7334 & 7.00 \\
\hline 1961 & 0.2100 & 4.76 & 0.8635 & 0.1125 & 8.89 & 0.7334 & 7.00 \\
\hline 1962 & 0.2100 & 4.76 & 0.8635 & 0.1125 & 8.89 & 0.7334 & 7.00 \\
\hline 1963 & 0.2100 & 4.76 & 0.8635 & 0.1125 & 8.89 & 0.7334 & 7.00 \\
\hline 1964 & 0.2100 & 4.76 & 0.8635 & 0.1125 & 8.89 & 0.7334 & 7.00 \\
\hline 1965 & 0.2100 & 4.76 & 0.8635 & 0.1125 & 8.89 & 0.7334 & 7.00 \\
\hline 1966 & 0.2100 & 4.76 & 0.8522 & 0.1125 & 8.89 & 0.7181 & 7.50 \\
\hline 1967 & 0.2100 & 4.76 & 0.8522 & 0.1125 & 8.89 & 0.7181 & 7.50 \\
\hline 1968 & 0.2100 & 4.76 & 0.8522 & 0.1125 & 8.89 & 0.7181 & 7.50 \\
\hline 1969 & 0.2100 & 4.76 & 0.8522 & 0.1125 & 8.89 & 0.7181 & 7.50 \\
\hline 1970 & 0.2100 & 4.76 & 0.8522 & 0.1125 & 8.89 & 0.7181 & 7.50 \\
\hline 1971 & 0.2100 & 4.76 & 0.8522 & 0.1125 & 8.89 & 0.7181 & 7.50 \\
\hline 1972 & 0.2100 & 4.76 & 0.8522 & 0.1125 & 8.89 & 0.7181 & 7.50 \\
\hline 1973 & 0.1875 & 5.33 & 0.8666 & 0.1000 & 10.00 & 0.6635 & 8.25 \\
\hline 1974 & 0.1875 & 5.33 & 0.8119 & 0.1000 & 10.00 & 0.6015 & 10.50 \\
\hline 1975 & 0.1875 & 5.33 & 0.8119 & 0.1000 & 10.00 & 0.6015 & 10.50 \\
\hline 1976 & 0.1875 & 5.33 & 0.8119 & 0.1000 & 10.00 & 0.6015 & 10.50 \\
\hline 1977 & 0.1875 & 5.33 & 0.8119 & 0.1000 & 10.00 & 0.6015 & 10.50 \\
\hline 1978 & 0.1875 & 5.33 & 0.7985 & 0.1000 & 10.00 & 0.5867 & 11.09 \\
\hline 1979 & 0.1875 & 5.33 & 0.7385 & 0.1000 & 10.00 & 0.5232 & 13.92 \\
\hline 1980 & 0.1875 & 5.33 & 0.6639 & 0.1000 & 10.00 & 0.4494 & 18.00 \\
\hline 1981 & 0.1875 & 5.33 & 0.6639 & 0.1000 & 10.00 & 0.4494 & 18.00 \\
\hline $1982^{1}$ & 0.1875 & 5.33 & 0.6989 & 0.1000 & 10.00 & 0.4833 & 16.00 \\
\hline $1982^{2}$ & 0.1800 & 5.35 & 0.6707 & 0.0960 & 10.42 & 0.4844 & 16.00 \\
\hline
\end{tabular}

Present Value Of Depreciation Allowances On A Unit Investment In Equipment And Buildings, Area A, 1950-1982

Source: For depreciation rates see incentive laws reported in text. For discount rates see Bank of Greece, Monthly Statistical Bulletin, various issues. ${ }^{1}$ First two quarters, ${ }^{2}$ Last two quarters. 
Using these expressions for $\mathrm{c}$ and the corresponding ones that can be derived from the above three if for example $\dot{q}=0$ and $\mathrm{q}=1$ or $\dot{q} \neq 0$ and $\mathrm{q}=1$, we have derived in Table (2) for the representative firm various values of $\mathrm{c}$ for the two kinds of capital assets, equipment and structures, for Greek manufacturing and for the period 19501982. The expressions for $\mathrm{c}$, denoted by $\mathrm{c}_{1}, \mathrm{c}_{2}$ for either equipment or structures, correspond to the following specifications:

$c_{1}=\left\{\begin{array}{l}(r+\delta)=c_{11} \\ (r+\delta-\dot{q})=c_{12}\end{array}\right\}$ period $1950-1972^{8}$

Table 2

User Cost Of Capital For Manufacturing Investment In Equipment And Structures, Area A, 1950-1982

\begin{tabular}{|c|c|c|c|c|c|c|c|c|}
\hline \multirow{3}{*}{ Year } & \multicolumn{4}{|c|}{ Equipment } & \multicolumn{4}{|c|}{ Structures } \\
\hline & \multicolumn{2}{|c|}{$\mathrm{C}_{1}$} & \multicolumn{2}{|c|}{$\mathrm{C}_{2}$} & \multicolumn{2}{|c|}{$\mathrm{C}_{1}$} & \multicolumn{2}{|c|}{$\mathrm{C}_{2}$} \\
\hline & $\mathrm{C}_{11}$ & $\mathrm{C}_{12}$ & $\mathrm{C}_{21}$ & $\mathrm{C}_{22}$ & $\mathrm{C}_{11}$ & $\mathrm{C}_{12}$ & $\mathrm{C}_{21}$ & $\mathrm{C}_{22}$ \\
\hline 1950 & 0.2200 & 0.2400 & & & 0.1750 & 0.0650 & & \\
\hline 1951 & 0.2200 & 0.1100 & & & 0.1750 & 0.0450 & & \\
\hline 1952 & 0.2200 & 0.1800 & & & 0.1750 & 0.1250 & & \\
\hline 1953 & 0.2200 & 0.1400 & & & 0.1750 & 0.1250 & & \\
\hline 1954 & 0.2200 & 0.0600 & & & 0.1550 & 0.0450 & & \\
\hline 1955 & 0.1900 & 0.1600 & & & 0.1450 & 0.0950 & & \\
\hline 1956 & 0.2000 & 0.1200 & & & 0.1550 & 0.1250 & & \\
\hline 1957 & 0.2000 & 0.1700 & & & 0.1550 & 0.1250 & & \\
\hline 1958 & 0.2000 & 0.2400 & & & 0.1550 & 0.1250 & & \\
\hline 1959 & 0.1792 & 0.1400 & & & 0.1342 & 0.1242 & & \\
\hline 1960 & 0.1700 & 0.0001 & & & 0.1250 & 0.1250 & & \\
\hline 1961 & 0.1700 & 0.1600 & & & 0.1250 & 0.1250 & & \\
\hline 1962 & 0.1700 & 0.0500 & & & 0.1250 & 0.0650 & & \\
\hline 1963 & 0.1700 & 0.1700 & & & 0.1250 & 0.1250 & & \\
\hline 1964 & 0.1700 & 0.1300 & & & 0.1250 & 0.1150 & & \\
\hline 1965 & 0.1700 & 0.1700 & & & 0.1250 & 0.0750 & & \\
\hline 1966 & 0.1750 & 0.1550 & & & 0.1300 & 0.0300 & & \\
\hline 1967 & 0.1750 & 0.1350 & & & 0.1300 & 0.1100 & & \\
\hline 1968 & 0.1750 & 0.1250 & & & 0.1300 & 0.1300 & & \\
\hline 1969 & 0.1750 & 0.2050 & & & 0.1300 & 0.1000 & & \\
\hline 1970 & 0.1750 & 0.1050 & & & 0.1300 & 0.0400 & & \\
\hline 1971 & 0.1750 & 0.0550 & & & 0.1300 & 0.1300 & & \\
\hline 1972 & 0.1750 & 0.0450 & & & 0.1300 & 0.0500 & & \\
\hline 1973 & & & 0.1945 & 0.0666 & & & 0.1603 & -0.0729 \\
\hline 1974 & & & 0.2289 & 0.0614 & & & 0.1995 & -0.0748 \\
\hline 1975 & & & 0.2289 & 0.0391 & & & 0.1995 & 0.1247 \\
\hline 1976 & & & 0.2289 & 0.0726 & & & 0.1995 & 0.0249 \\
\hline 1977 & & & 0.2289 & 0.1172 & & & 0.1995 & -0.0125 \\
\hline 1978 & & & 0.2372 & 0.1022 & & & 0.2083 & -0.0303 \\
\hline 1979 & & & 0.2779 & 0.1384 & & & 0.2515 & -0.0334 \\
\hline 1980 & & & 0.3383 & 0.1570 & & & 0.3151 & 0.0737 \\
\hline 1981 & & & 0.3521 & 0.1509 & & & 0.3342 & 0.1635 \\
\hline 1982 & & & 0.3200 & 0.1108 & & & 0.3000 & 0.1745 \\
\hline
\end{tabular}

Source: See text 
$c_{2}=\left\{\begin{array}{l}(r+\delta) \frac{(1-t z)}{(1-t)}=c_{21} \\ (r+\delta-\dot{q}) \frac{(1-t z)}{(1-t)}=c_{22}\end{array}\right\}$ period 1973-1982

where

$z=\sum_{i=1}^{n} d_{i}(1+r)^{-i} \quad($ see Table 1$)$

The values of $r$ were taken to be the same as those used for the calculation of $z$. The corporate income tax rates used were those for companies whose shares are listed on the Athens Stock Exchange under the assumption that the bulk of manufacturing investment in Greece is undertaken by these companies. Jorgenson's method of estimating the replacement rate was adopted here. Consulting various Greek studies undertaken in the past (Krengel and Mertens, 1966, Kintis, 1973, Handrinos, 1979), the asset lifetime N for equipment and structures was taken to be 25 and 45 years respectively; then according to Hall and Jorgenson (1971) where $\delta=2.5 \frac{1}{N}$, it was taken $\delta=0.1$ for equipment and $\delta=0.055$ for structures.

Finally, the derivation of $q$ was made assuming perfect foresight by using some unpublished data of the former Ministry of Co-ordination, provided for the period 1948-1982. What it can be observed from these series is the great variability in the values of these indices (especially those for equipment) in the different years, where some small increases are followed by immense jumps in the succeeding years. This has an effect of $\overline{\boldsymbol{C}}$ that further causes great variation in the value of $\mathrm{c}$.

In Figures (1), (2), (3), (4), the trend of c over the period 1950-1982 is indicated. When expectations are static (i.e. $\dot{q}=0$ ), c is kept almost constant for the three decade period for both capital assets (see Figures 1 and 2). Only during the last years of the sample has c started to display some upward trend.

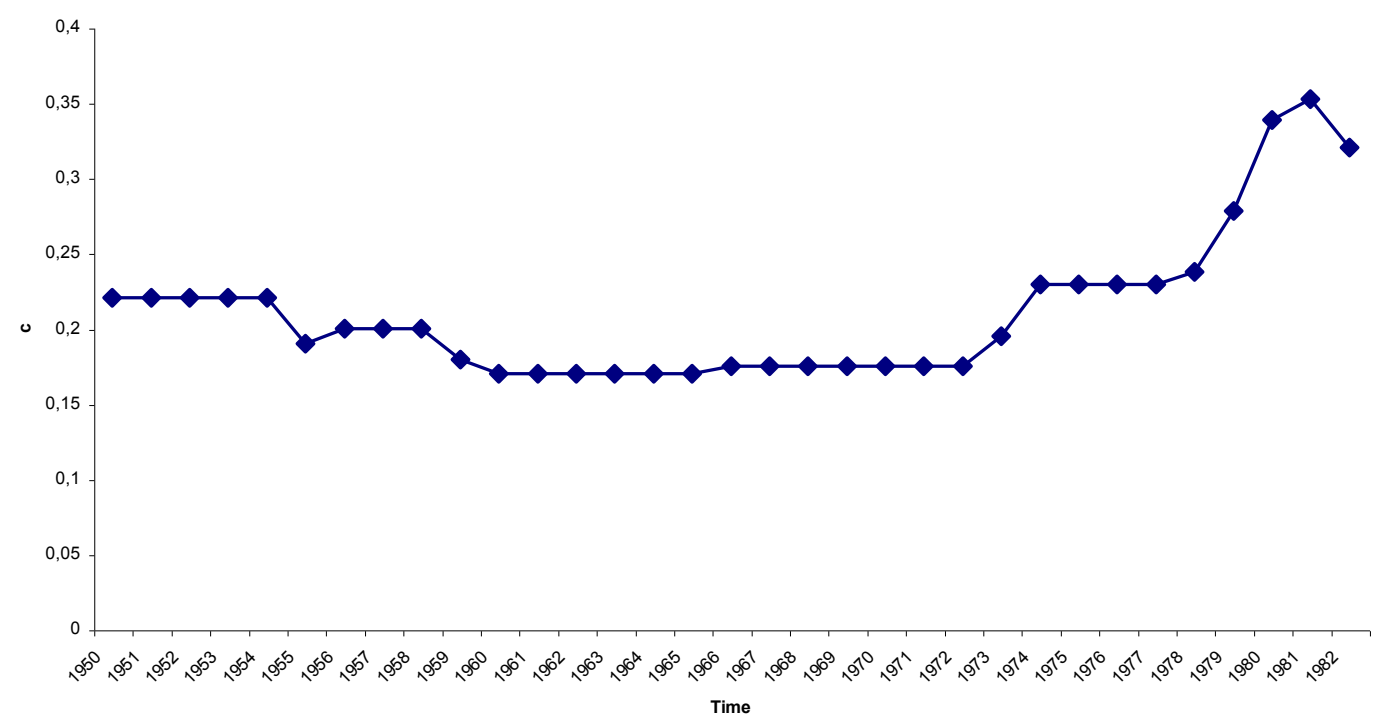

Figure 1: Values of "C" for Equipment [ $\left.c_{11}(1950-1972), c_{21}(1973-1982)\right]$ 


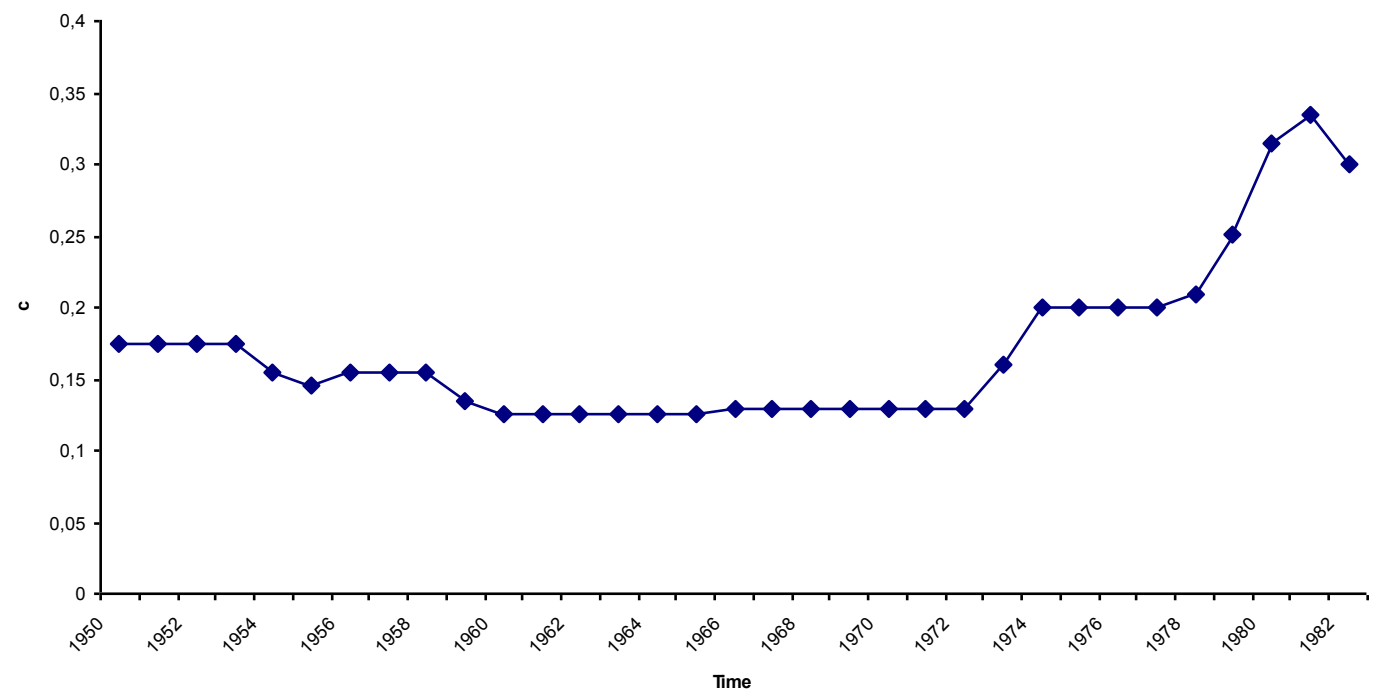

Figure 2: Values Of “C" For Structures [ $c_{11}\left(\mathbf{1 9 5 0 - 1 9 7 2 ) ,} \mathbf{c}_{21}(1973-1982)\right]$

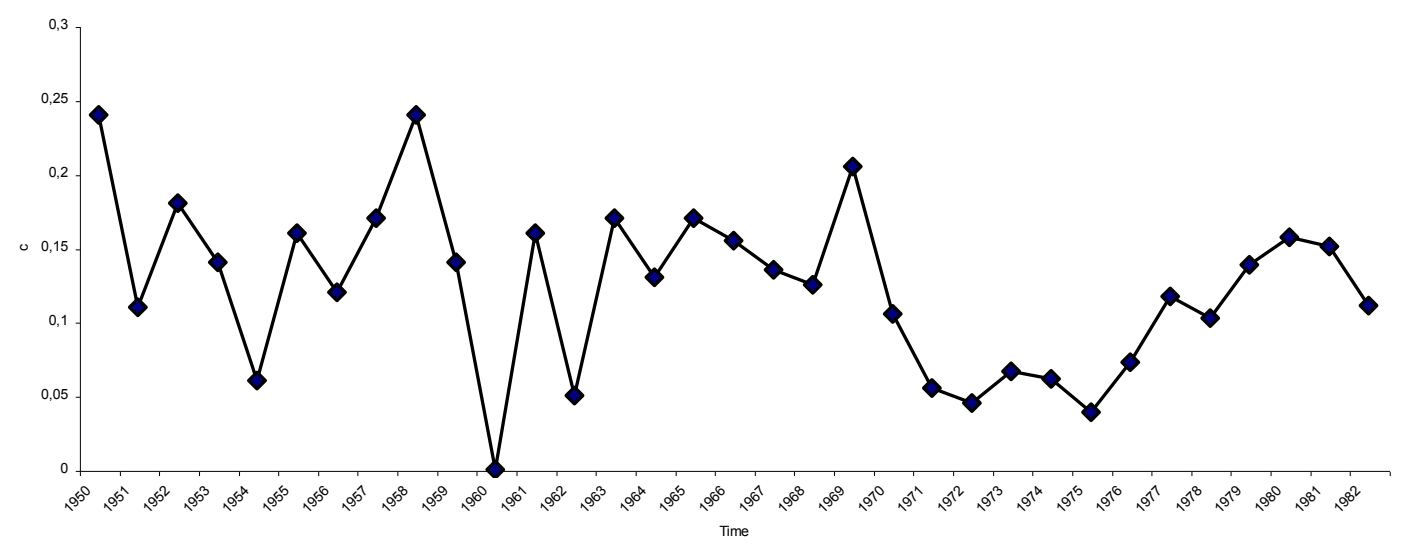

Figure 3: Values Of "C" For Equipment [c $c_{12}(1950-1972), c_{22}$ (1973-1982)] 


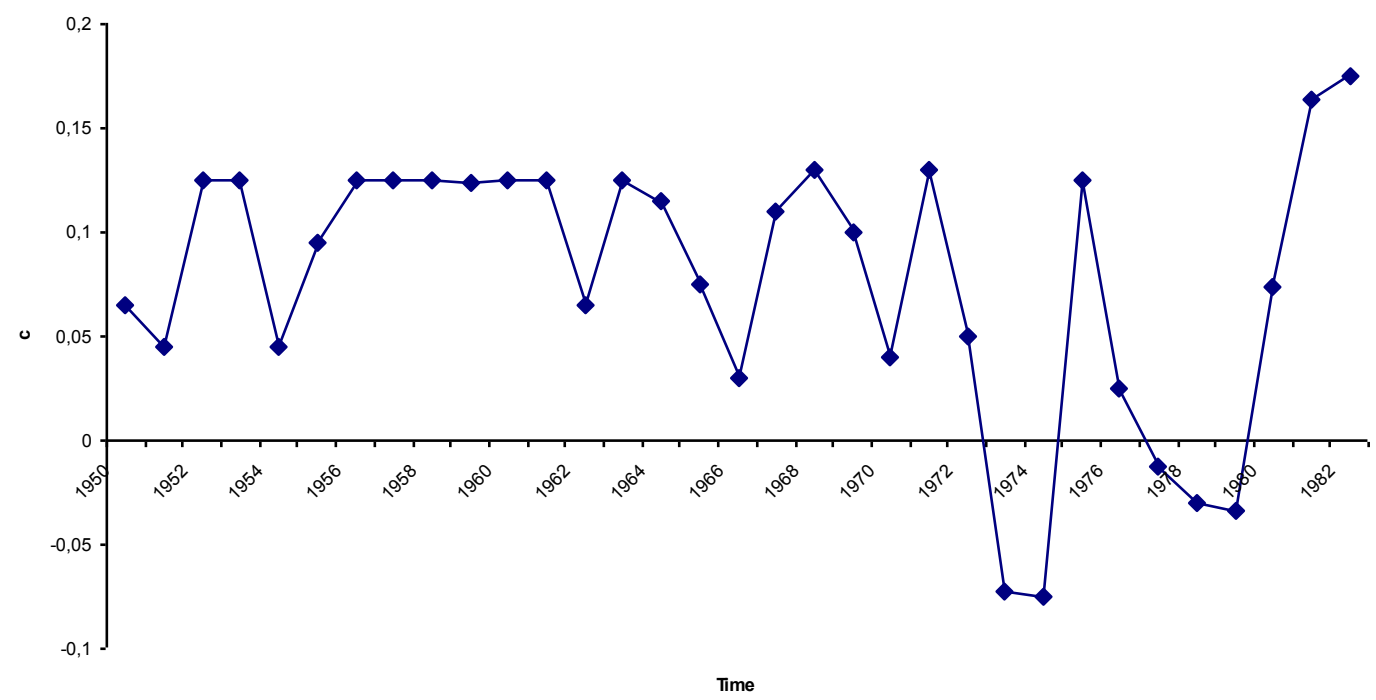

Figure 4: Values Of “C" For Structures [ $\left.c_{12}(1950-1972), c_{22}(1973-1982)\right]$

\section{CONCLUSION}

The examination of the effect on investment of some main incentive measures provided by the Greek authorities over the prior years has shown that these measures had not much contribution in positively influencing the rate of investment expenditure. The fiscal variables used, according to the specifications of the neoclassical theory, were the rate of corporate taxation and the fiscal parameter $\mathrm{z}$ into which changes in depreciation policy and the various tax allowances in use during all this period were incorporated. The test of fiscal parameters on investment was made for the two kinds of capital assets, equipment, and structures.

It was indicated that the corporate tax rate had remained almost constant over the period. In addition the value of $z$, incorporating depreciation allowances only, did not present any major variations for either equipment or structures. Thus c, the cost of capital variable, used in neoclassical theory for tax incentives' evaluation, was not affected much by tax provisions and in its turn could not affect decisively the desired level of capital stock and thus the amount of net investment.

So, investment behavior in Greek manufacturing cannot be studied using the neoclassical theory of capital accumulation (in its part concerning changes in user cost as important investment determinants), since there is no substitution effect of investment deductions (defined in a more general sense) at least for the period under investigation, or there is a small one since $\mathrm{c}$ is not absolutely constant (in which case Jorgenson's model would be reduced to the flexible accelerator): while $\lambda$ may be inoperative and excluded from the calculations of $\mathrm{c}, \mathrm{t}$ and $\mathrm{z}$ still remain operative.

\section{SUGGESTIONS FOR FUTURE RESEARCH}

Excluding, in the above sense, the neoclassical theory as a source of study of the investment behavior in Greek manufacturing, our search for the appropriate model has to be directed towards other theories of the more $a d$ hoc nature which incorporate measures of profits or the availability of internal funds as possible determinants of investment. These internal financing sources could enter in a properly specified investment function, either as determinants of the speed of adjustment of desired to actual capital stock or as determinants of the desired capital stock itself. The role of incentives then could be entered in the above framework as affecting the liquidity variables, and we could try to examine what this 'liquidity' effect of incentives could be, if any. 


\section{ENDNOTES}

1. For a straight line depreciation pattern, $d_{i}=1 / \mathrm{n}$, where $\mathrm{n}$ is the lifetime of the asset for tax purposes, and then

$$
z=\sum_{i=1}^{\infty} d_{i}(1+r)^{-i}=\frac{1}{n} \sum_{i=1}^{n}(1+r)^{-i}=\frac{1}{n}\left(\frac{(1+r)^{n}-1}{r(1+r)^{n}}\right)
$$

In continuous time the discounted value of depreciation allowances per unit of capital $\left(\mathrm{K}_{0}\right)$ is

$$
z=\int_{0}^{n} \frac{1 / n K_{0}}{K_{0}} e^{-r t} d_{t}=\frac{1}{n r}\left(1-e^{-r n}\right)
$$

2. Similar results for this case are given in Brown (1948), and Musgrave (1959).

3. In case of an initial allowance $\left(\lambda_{1}\right)$ the value of $\mathrm{z}$ will be

$$
z=\sum_{i=1}^{\infty} d_{i}(1+r)^{-i} \cdot\left(1-\lambda_{1}\right)
$$

since $\lambda_{1}$ increases the normal depreciation charge in the first year, but annual depreciation charges in later years are smaller than they would have been if there were no initial allowances.

4. These rates have been derived by a very detailed and scrutinized research of various incentive laws applied in Greece for an earlier three decade period (1950-1982). We report for this period since this belongs to a greater (1950-2000) period which is currently investigated for the assessment of incentive provisions for manufacturing investment in Greece and for which smaller period we have already gathered material for investigation. From a preliminary research, one can say that this first period's incentive provisions are better offered for research under the neoclassical theory, while recent incentive measures are mainly capital related provisions of the grant supporting style. Incentive laws that have been searched for depreciation rate changes are: L 942/1949, L 2901/1954, L 3765/1957, EL 147/1967, PD 88/1973, LD 1078/1971, L 1116/1981, L 1262/1982 (where L=Law, EL = Emergency Law, PD = Presidential Degree, $\mathrm{LD}=$ Legislative Degree).

5. See Coutsoumaris (1963), pp. 133-137, for reasons of concentration in the Athens area, and Kottis (1980), pp. 2125.

6. The relevant incentive laws which have been searched and refer to these provisions are: EL 942/1949,LD 2176/1952,LD 3213/1955,LD 4002/1959, EL 147/1967, LD 1078/1971, LD 1212/1972, LD 1312/1972, LD 1377/1973, L 331/1974, L 289/1976, L 849/1978, L 1116/1981, L 1262/1982.

7. In fact the application of depreciation allowances alone were absorbing almost 70 per cent (buildings) or 80 per cent (equipment) from net profits, with little left to be taxed if no other allowances were in use. Of course $\mathrm{z}$ refers to a present value of future deductions. But as has been found (Anastassiou, 2005), the amounts of investment expenditures undertaken during all these years were much higher than the amount of profits, and deductions on these investments for depreciation purposes were carried forward so in a specific year they were reducing (if not nullifying) substantially taxable profits.

8. During this period no investment allowances were existent, and furthermore no tax obligations from new investments were in effect for the representative firm, since tax-free reserves and investment deductions were reducing taxable income to zero (as it was indicated before). Thus fiscal variables had no effect in the formulation of the user cost of capital.

\section{REFERENCES}

1. Anastassiou, T. A., Are Tax Incentive Provisions Always Operative? Evidence from the Greek Manufacturing Industry, Journal of Applied Business Research, forthcoming, 2005.

2. Brown, E. C., Business-Income Taxation and Investment Incentives in Metzler, L.A. et al, Income Employment and Public Policy - Essays in Honor of Alvin H. Hansen, W. W. Norton and Co., New York, 1948.

3. Coen, R. M., Effects of Tax Policy on Investment in Manufacturing, American Economic Review, Vol. 58, pp.200-211, 1968. 
4. Coen, R. M., The Effects of Cash Flow on the Speed of Adjustment, in Fromm, G. (ed.), Tax Incentives and Capital Spending, Brookings Institution, Washington D.C.,1971.

5. Coutsoumaris, G., The Morphology of Greek Industry, Center of Planning and Economic Research, Athens, 1963.

6. Hall, R. E. and Jorgenson, D. W., Tax Policy and Investment Behavior, American Economic Review, Vol. 57, pp. 247-259, 1967.

7. Hall, R. E. and Jorgenson, D. W., Application of the Theory of Optimum Capital Accumulation, in Fromm, G. (ed.), Tax Incentives and Capital Spending, Brookings Institution, Washington D.C., 1971.

8. Handrinos, S., The Estimation of Policy Implications of Alternative Forms of Factor Demand Equations, Ph.D. Thesis, University of Manchester, 1979.

9. Kintis, A. A., The Demand for Labor in Greek Manufacturing, Center of Planning and Economic Research, Athens, 1973.

10. Kottis,G. H., Industrial Decentralization and Regional Development, Institute of Economic and Industrial Research, Athens, (in Greek), 1980.

11. Krengel, R. and Mertens, D., Fixed Capital Stock and Future Investment in Greek Manufacturing, Center of Planning and Economic Research, Athens, 1966.

12. Musgrave, R., The Theory of Public Finance, McGraw Hill, New York, 1959.

\section{NOTES}




\section{NOTES}

